\title{
Право
}

УДК 346.7

\author{
Shpinev Iu $S$ \\ Institute of state and law of the Russian Academy of Sciences, Moscow
}

\section{Green economy and issues of its legal regulation}

\begin{abstract}
The article deals with the issues of legal regulation of the «green» economy. The author examines the reasons why society is trying to move from the classical model of economic growth to a «green» economy. The main international agreements and regulations governing this area are considered. Different approaches to the definition of «green economy» are outlined. In conclusion, the author concludes that despite the active development of legislation in this area, the necessary economic effect is not felt, which is primarily due to the prevalence of administrative measures of interaction between the state and market participants, which cannot give positive results in the present reality.

Keywords: green economy, sustainable development, environment, nature management.

For citation: Shpinev Iu. S. Green economy and issues of its legal regulation // Humanitarian scientific journal. 2020. №2. p.55-63.

This is an open access article distributed under the terms of Creative Commons Attribution License (CC-BY 4.0).
\end{abstract}

The beginning of the 21 st century can be described as the beginning of the century of new economic technologies. Just think about the digital economy, the social economy, and, of course, the "green" economy.

Today, humanity is aware of all the consequences of an irrational and consumer attitude to natural resources and the entire ecosystem of the Earth as a whole, and gradually, step by step, begins to make attempts, if not to stop the destruction of the planet's nature, then at least to prevent the approaching environmental disasters associated with human activity [1].

One of these steps is the desire to move from the traditional model of economic growth, the so-called «brown» economy to the «green»economy [2]. All developed countries are trying to move not just to an innovative model of economic growth, but to an economy that promotes and strives for the most efficient use of natural resources, reduces poverty, and solves socio-economic and environmental problems. The so-called «green economy» is aimed at solving the latter to a greater extent.

Out of the 17 sustainable development goals, developed taking into account the views of 193 States and adopted at the UN Summit on sustainable development until 2030 (hereinafter the UN Summit on sustainable development) at least 7 relate to the conservation and careful use of the earth's nature [3].

One of the priority goals is declared careful attitude to water resources.

Another goal is the need for universal provision of modern and reliable energy supply. In terms of the green economy, this goal can include increasing 
the share of renewable energy sources in the total amount of energy consumed in the world, as well as facilitating access to advanced scientific knowledge for developing countries.

This goal seems to be one of the most difficult, especially in terms of its implementation in developing countries, since the development of a weak economy requires enormous energy costs, while at the present stage of development, the cheapest and most affordable energy sources for such countries can not be called economically clean. The use of environmentally friendly, including renewable sources of energy requires large financial costs, which developing countries cannot cope with alone.

Ensuring a sustainable consumption and production model is considered an important direction in respect of natural resources. To implement it, it is proposed:

- reduction of waste production by organizing their differentiated collection, grinding, recycling for secondary use;

- universal awareness of the world's population about sustainable development, as well as promotion of a harmonious way of life with nature;

- maximum efficient use of natural resources;

- reducing the global amount of food waste, including significantly reducing food losses both in the value chain and post-harvest losses;

- comprehensive support to developing countries on the way to the most efficient production and consumption models;

- interaction with multinational companies and corporations in order to encourage them to use rational production models and then reflect such methods in their publicly available reports;

- maximum reduction in the provision of inefficient subsidies in the field of extraction and use of fossil fuels, contributing to its inefficient consumption by reforming the tax system and further reducing such subsidies;

- reducing the negative consequences for developing countries, including environmental and economic ones, in the transition to a sustainable consumption and production model.

Much attention is paid worldwide to climate change and its consequences. In order to combat global warming, it is proposed to develop and introduce measures aimed at climate change in national strategies and development plans of all countries, as well as to inform the population about the need to comply with climate change prevention measures.

Given that two-thirds of the earth's surface is occupied by oceans, an important area of environmental conservation is the rational use of natural water resources of the world's oceans, including:

- a significant reduction in pollution of the world's oceans and marine environment by all types of sources, including nutrients; 
- providing small fishing companies with open access to marine resources and markets;

- encouraging the transfer of innovative marine technologies from developed to developing countries to improve the health of the world's oceans;

- preservation of at least 10 per cent of marine and coastal areas untouched by human activity in accordance with international and national law, guided by scientific data;

- assistance in the use of marine resources to increase economic benefits through the sound management of fish stocks and aquaculture, especially for small island States and least developed countries;

- prohibiting methods of subsidizing the fishing industry that promote overfishing, as well as illegal and unregulated fishing, while taking into account the interests of developing and least developed countries;

- ensuring compliance with the United Nations Convention on the law of the sea, including with regard to the conservation and careful use of the ocean and marine resources.

The conservation and restoration of the land ecosystem is no less important than the conservation of the world's oceans. To meet this global challenge, the States agreed to work together on its rational use, including careful management of forests, and jointly stop desertification, land degradation and loss of biodiversity. More detailed tasks for achieving this goal include:

- universal adherence to the principle of sustainable use of forests, reduction of deforestation, as well as increased afforestation;

- protection, restoration and careful use of terrestrial and freshwater ecosystems, including forests, mountains and swamps;

- restoration of land affected by droughts and floods, as well as desertification;

- implementation of comprehensive measures to reduce the rate of decline of natural habitat and stop the loss of biodiversity;

- urgent protection of endangered species;

- organization of financing for the conservation and sustainable use of ecosystems and biodiversity;

- implementation of measures to prevent the introduction of parasitic species and reduce their impact on ecosystems;

- preserving the biodiversity of mountain ecosystems to improve the ability to preserve the benefits necessary for sustainable development;

- implementation of the fight against poaching, as well as the suppression of illegal trade in prohibited species of flora and fauna;

- the introduction of values based on ecosystems and biodiversity in national and local plans; 
- encourage and support the fight against poaching and illegal trade in prohibited species, including through the socio-economic development of habitat regions.

As can be seen from the listed goals for sustainable development, humanity has set itself ambitious goals for the conservation of natural resources. In many ways, it is the «green» economy that should contribute to solving these problems.

The Russian Federation participates in most international environmental organizations. As a member of the UN, our country has committed itself to sustainable development until 2030 in order to achieve the goals outlined above, one of the key areas of which is the environment.

Russia agrees with most countries in the need to develop a «green» economy $[4,66]$. The policy of our country is carried out in accordance with the priorities of national interests in accordance with the international obligations assumed. In this regard, when moving towards a «green» economy, we need to take into account the possible risks associated primarily with the fact that the Russian economy largely depends on the export of hydrocarbons. In this regard, in order to maintain and develop competitiveness with other countries within the framework of the «green» strategy, we need not only to reduce the energy intensity of our economy, but also to implement its overall modernization [5].

Federal law № $172 \mathrm{FZ}$ of 28.06.2014 «On strategic planning»[6] gives an important place to the environmental component of economic entities, including rational use of natural resources and environmental protection. Thus, according to paragraph 2 of article 24 of this law, the forecast of socio-economic development of the Russian Federation for the long-term period contains, among other things, the main indicators of the state of the environment and natural resources.

It should be noted that for long-term strategic planning, it is necessary to systematize and further take into account such elements as:

- the fundamental role of the state in the organization and management of natural resources;

- the need for a unified and structured system of state planning;

- a modern system of accounting, control and adjustment if necessary of the elements of the structure;

- the long-term nature of planning elements such as the environment and nature management.

In this case, environmental goals and requirements are a necessary component for socio-economic planning [7, 25].

Thus, currently in our country, legislative activity is being activated in terms of regulating the resource-saving and environmental sphere. This process develops after the introduction in enterprises of «green» technologies $[8,12]$, the emergence of «green» sectors of the economy [9, 7], the emergence of new financial instruments of «green» economy [10], the emergence of requirements on disclosure of information by companies in the «green» sector [11]. 
One of the first and perhaps the most important laws in the field of «green» economy can be safely called Federal law № 7-FZ of 10.01.2002 «On environmental protection» [12], which sets the directions of state policy in the field of nature management and the environment. This normative act regulates legal relations in the sphere of mutual influence of people and nature, which take place during the implementation of business activities that affect the environment.

This law regulates many issues related to the «green economy» in one way or another, including:

- main principles of environmental protection;

- environmental objects, types of pollutants, as well as types of objects that can have a negative impact on the environment;

- the main powers of state and local government bodies to regulate legal relations in the field of environmental protection,

- issues of economic regulation, as well as regulation in the field of the environment;

- requirements in the field of environmental protection;

- regulations on state environmental and industrial supervision;

- liability for violation of environmental legislation and other issues.

It is also important to note that the law contains definitions of the main terms used in the field of the environment.

Another important document in the field of ecology is the Strategy of environmental security of the Russian Federation for the period up to 2025 [13], which is the basis for the formation and implementation of state policy in the field of economic security. The strategy contains an assessment of the current state of environmental security on issues raised at the UN Summit on sustainable development, a list of challenges and threats to economic security, as well as goals and objectives of state activities in the field of the environment.

Thus, in accordance with the Strategy, global challenges to economic security include climate change, the reduction of natural resources, the negative consequences of environmental degradation and the reduction of biological diversity.

An indirect indication of the need for a «green» economy can be found in the Fundamentals of state policy in the field of environmental development in Russia [14]. According to paragraph 7, the main goal of the state policy in the field of environmental development is to identify and solve problems that help the development of the economy. This approach implies the preservation of a healthy environment and biological diversity, as well as natural resources.

It should be noted that despite the widespread use of the term «green economy», there is no generally accepted definition of it. It is believed that the term «green economy» first appeared in 1989 in the work of British environmental economists D. Pearce, A. Markandii and E. Barbier [15, 45], in which scientists showed that traditional economic development can lead to the 
destruction of natural capital and threatens the prosperity of civilization in the long term $[16,70]$.

According to the definition proposed by UNEP, «green economy» is understood as economic activity that, on the one hand, contributes to improving human welfare and social justice, and on the other hand, reduces the risks of preserving the environment $[17,73]$.

Among the regulations in the field of «green economy», we should mention the national project «Ecology», the passport of which was approved following the meeting of the Presidium of the presidential Council for strategic development and national projects on December 24, 2018 [18].

The environmental programs «Environmental protection» [19], «Reproduction and use of natural resources» [20], «Development of the water management complex of the Russian Federation in 2012-2020» [21] and «Protection of lake Baikal and socio-economic development of the Baikal natural territory for 2013-2020» [22] were approved.

Thus, quite a number of regulations regulating environmental protection have been adopted recently. But there is no real transition to a «green» economy. There is an opinion in the scientific literature, and we agree with it in principle, that the reason for the current situation is that the measures implemented by the Government of the Russian Federation are more administrative in nature and use mainly sanctions. In the current state of Affairs, this approach is ineffective, because organizations either do not benefit from investing in the «green» economy, or they simply do not have the necessary finances. Today it is much easier to pay a fine than to invest in the environment $[1,58]$.

The state, realizing the public interests of society, regulates business activities by various methods $[23,56]$, however, as long as the normative acts regulating the sphere of the «green» economy have mainly a «whip» in their Arsenal, real progress in this area can not be expected. Imperative methods of regulating business activity should always alternate with dispositive ones [24, 75]. In addition, it is necessary to change the stereotype inherent in our society that the main indicator of economic growth, and, consequently, progress, is the growth of gross domestic product and move to more socially oriented indicators of development.

\section{Literature}

1. Zankovsky S. S. Energy security of Russia: legal issues // Energy law. 2006. № 2. P. 66.

2. Kodaneva S. I. From «brown economy» to «green». Russian and foreign experience / / Russia and the modern world. 2020. № 1 (106). Pp. 44-66.

3. Summit on sustainable development 2015. New York. October 25-27. 2015. [Electronic resource]. - Access mode-URL: http://www.unepcom.ru/development/summit2015.html (accessed: 09.12.2020).

4. Yakovlev I. A., Kabir L. S., Rakov I. D. «Green» investments in Russia: main trends // Economics: theory and practice. 2017. № 3 (47). Pp. 66-75. 
5. Platonova I. N. Sustainable development of the world economy and competitiveness of Russia // Russian foreign economic Bulletin. 2014. № 9. Pp. 49-64.

6. Federal law № 172 FZ of 28.06.2014 «On strategic planning» / / Rossiyskaya Gazeta. 03.07.2014. № 146 .

7. Vypkhanova G. V., Zhavoronkova N. G. State environmental policy and strategic planning documents // Environmental law. 2016. № 3. Pp. 24-29.

8. Timofeeva S. S. «Green economy», «green jobs» in Russia and new production risks / / XXI century. Technosphere security. 2016. Vol. 1. № 2. P. 10-20.

9. Rater S. V., Klochkov V. V. Analysis of the effectiveness of localization in Russia of production of equipment for green energy / / Financial Analytics: problems and solutions. 2015. № 38 (272). P. 2-14.

10. Frolova E. E. Green bonds in the Nordic countries: features of development and legal regulation. Journal of the Belarusian State University. Right. 2020. P. 43-48.

11. Analytical review of corporate non-financial reports: 2015-2016 years of issue / Feoktistova E. N. [et al.].

12. Federal law № 7-FZ of 10.01.2002 «On environmental protection»// Rossiyskaya Gazeta. 12.01.2002. № 6.

13. Decree of the President of the Russian Federation of 19.04 .2017 «On the strategy of environmental safety for the period up to 2025». [Electronic resource]. - Access mode-URL: http://publication.pravo.gov.ru/Document/View/0001201704200016 (accessed: 09.12.2020).

14. Decree of the President of the Russian Federation of 30.04.2012 «On the Fundamentals of state policy in the field of environmental development of the Russian Federation for the period up to 2030». [Electronic resource]. - Access mode-URL: http://www.kremlin.ru/events/president/news/15177 (accessed: 09.12.2020).

15. Bobylev S. N., Goryacheva A. A., Nemova V. I. «Green» economy: project approach. Materials of the V Moscow economic forum // State administration. Electronic Bulletin. Issue № 64. 2017. October, Pp. 34-44.

16. Kodanova S. I. «Green investments» in Russia and abroad: problems, mechanisms, perspective // Russia and the modern world. 2020. № 3 (108) P. 68-88. DOI: 10.31249/rsm/2020.03.05.

17. Spiridonova A. V. Ekologicheskie investing in the Russian Federation: theoretical and legal approach // Bulletin of SUSU. The Law Series. 2020. Vol. 20. № 1. Pp. 72-79. DOI: $10.14529 / \mathrm{dfc} 200111$.

18. Passport of the national project «Ecology». Approved following a meeting of the Presidium of the presidential Council for strategic development. [Electronic resource]. Access mode-URL: http://government.ru/info/35569/ (accessed: 09.12.2020).

19. State program «Environmental Protection». Approved by Government Decree № 326 of April 15, 2014. [Electronic resource]. - Access mode-URL: http://government.ru/rugovclassifier/874/events/ (accessed: 09.12.2020).

20. State program «Environmental protection». Approved by Government Decree № 322 of April 15, 2014. [Electronic resource]. - Access mode-URL: http://government.ru/rugovclassifier/817/events/ (accessed: 09.12.2020).

21. State program «Development of the water management complex of the Russian Federation in 2012-2020». [Electronic resource]. - Access mode-URL: https:/gosdokladecology.ru/2017/gosudarstvennoe-upravlenie/gosudarstvennye-programmy/ (accessed: 09.12.2020).

22. State program «Protection of lake Baikal and socio-economic development of the Baikal natural territory for 2013-2020». [Electronic resource]. - Access mode-URL: 
https://gosdoklad-ecology.ru/2017/gosudarstvennoe-upravlenie/gosudarstvennye-programmy / (accessed: 09.12.2020).

23. Cherkesova L. I. Integration processes of the EAEU and their impact on the transformation of business legislation in Russia // Gaps in Russian legislation. 2020. № 6. Pp. 55-62.

24. Battakov P. P. Characteristics of entrepreneurial activity // Law and Economics. 2012. № 11 (297). Pp. 73-77.

\section{Reference}

1. Zankovskij S. S. Energeticheskaya bezopasnost' Rossii: pravovye voprosy // Energeticheskoe pravo. 2006. № 2. S. 66.

2. Kodaneva S.I. Ot «korichnevoj ekonomiki» - k «zelenoj». Rossijskij i zarubezhnyj opyt // Rossiya i sovremennyj mir. 2020. № 1 (106). S. 44-66.

3. Sammit po ustojchivomu razvitiyu 2015. N'yu-Jork. 25-27 oktyabrya. 2015. [Elektronnyj resurs]. - Rezhim dostupa - URL: http://www.unepcom.ru/development/summit2015.html (Data obrashcheniya: 09.12.2020).

4. Yakovlev I. A., Kabir L. S., Rakov I. D. «Zelenye» investicii v Rossii: osnovnye tendencii // Ekonomika: teoriya i praktika. 2017. № 3 (47). S. 66-75.

5. Platonova I. N. Ustojchivoe razvitie mirovoj ekonomiki i konkurentosposobnost' Rossii // Rossijskij vneshneekonomicheskij vestnik. 2014. № 9. S. 49-64.

6. Federal'nyj zakon ot 28.06.2014 № $172 \mathrm{FZ} \mathrm{«O} \mathrm{strategicheskom} \mathrm{planirovanii»//}$ Rossijskaya gazeta. 03.07.2014. № 146.

7. Vyphanova G. V., ZHavoronkova N. G. Gosudarstvennaya ekologicheskaya politika i dokumenty strategicheskogo planirovaniya // Ekologicheskoe pravo. 2016. № 3. S. 24-29.

8. Timofeeva S. S. «Zelenaya ekonomika», «zelenye rabochie mesta»v Rossii i novye proizvodstvennye riski // HKHI vek. Tekhnosfernaya bezopasnost'. 2016. T.1. № 2. S. 10-20.

9. Rater S. V., Klochkov V. V. Analiz effektivnosti lokalizacii v Rossii proizvodstva oborudovaniya dlya zelenoj energetiki // Finansovaya analitika: problemy i resheniya. 2015. № 38 (272). S. 2-14.

10. Frolova E. E. Zelenye obligacii v stranah Severnoj Evropy: osobennosti razvitiya i pravovogo regulirovaniya. ZHurnal Belorusskogo gosudarstvennogo universiteta. Pravo. 2020. S 43-48.

11. Analiticheskij obzor korporativnyh nefinansovyh otchetov: 2015-2016 gody vypuska / Feoktistova E. N. [i dr.].

12. Federal'nyj zakon ot 10.01.2002 №7-FZ «Ob ohrane okruzhayushchej sredy»// Rossijskaya gazeta. 12.01.2002. № 6 .

13. Ukaz Prezidenta Rossijskoj Federacii ot 19.04.2017 «O Strategii ekologicheskoj bezopasnosti na period do 2025 goda». [Elektronnyj resurs]. — Rezhim dostupa — URL: http://publication.pravo.gov.ru/Document/View/0001201704200016 (Data obrashcheniya: 09.12.2020).

14. Ukaz Prezidenta Rossijskoj Federacii ot 30.04.2012 «Ob Osnovah gosudarstvennoj politiki v oblasti ekologicheskogo razvitiya Rossijskoj Federacii na period do 2030 goda». [Elektronnyj resurs]. - Rezhim dostupa - URL: http://www.kremlin.ru/events/president/news/15177 (Data obrashcheniya: 09.12.2020).

15. Bobylev S. N., Goryacheva A. A., Nemova V. I. «Zelenaya» ekonomika: proektnyj podhod. Materialy V Moskovskogo ekonomicheskogo foruma // Gosudarstvennoe upravlenie. Elektronnyj vestnik. Vypusk № 64. 2017. Oktyabr'. S. 34-44. 
16. Kodaneva S. I. «Zelenye investicii» v Rossii i za rubezhom: problemy, mekhanizmy, perspektivy // Rossiya i sovremennyj mir. 2020. № 3 (108) S. 68-88. DOI: 10.31249/rsm/2020.03.05.

17. Spiridonova A. V. Ekoloicheskoe investirovanie v Rossijskoj Federacii: teoretikopravovoj podhod // Vestnik YUUrGU. Seriya Pravo. 2020. T. 20. № 1. S. 72-79. DOI: $10.14529 / \mathrm{dfc} 200111$.

18. Pasport nacional'nogo proekta «Ekologiya». Utverzhden po itogam zasedaniya prezidiuma Soveta pri Prezidente Rossijskoj Federacii po strategicheskomu razvitiyu. [Elektronnyj resurs]. — Rezhim dostupa — URL: http://government.ru/info/35569/ (Data obrashcheniya: 09.12.2020).

19. Gosudarstvennaya programma «Ohrana okruzhayushchej sredy». Utverzhdena postanovleniem Pravitel'stva ot 15 aprelya 2014 goda № 326. [Elektronnyj resurs]. — Rezhim dostupa - URL: http:/government.ru/rugovclassifier/874/events/ (Data obrashcheniya: 09.12.2020).

20. Gosudarstvennaya programma «Ohrana okruzhayushchej sredy». Utverzhdena postanovleniem Pravitel'stva ot 15 aprelya 2014 goda № 322. [Elektronnyj resurs]. — Rezhim dostupa - URL: http:/government.ru/rugovclassifier/817/events/ (Data obrashcheniya: 09.12.2020).

21. Gosudarstvennaya programma «Razvitie vodohozyajstvennogo kompleksa Rossijskoj Federacii 2012-2020 godah». [Elektronnyj resurs]. - Rezhim dostupa - URL: https:/gosdoklad-ecology.ru/2017/gosudarstvennoe-upravlenie/gosudarstvennye-programmy/ (Data obrashcheniya: 09.12.2020).

22. Gosudarstvennaya programma «Ohrana ozera Bajkal i social'no-ekonomicheskoe razvitie Bajkal'skoj prirodnoj territorii na 2013-2020 gody». [Elektronnyj resurs]. — Rezhim dostupa - URL: https://gosdoklad-ecology.ru/2017/gosudarstvennoeupravlenie/gosudarstvennye-programmy/ (Data obrashcheniya: 09.12.2020).

23. CHerkesova L. I. Integracionnye processy EAES $i$ ih vliyanie na transformaciyu predprinimatel'skogo zakonodatel'stva Rossii // Probely v Rossijskom zakonodatel'stve. 2020. № 6. S. 55-62.

24. Battahov P. P. Priznaki predprinimatel'skoj deyatel'nosti // Pravo i ekonomika. 2012. № 11 (297). S. 73-77. 